\title{
ПОНИМАНИЕ КАК СВЯЗЬ СЛОВА И ОБРАЗА (В АСПЕКТЕ ПСИХИЧЕСКИХ ОБРАЗОВ ВЫСШИХ ПОРЯДКОВ)
}

\begin{abstract}
Аннотация. В статье анализируется феномен понимания наглядной информации, находящейся в образах высших порядков. Автор опирается на разработанную ранее модель образов-интеграторов различных порядков, согласно которой, наглядная инбормация обобщается независимо от вербальной, формируя все более усложняющиеся образования. В модели утверждается, что образы первого порядка - фотограбические образы, второго порядка - классические вторичные образы; третьего порядка - обобщенные образы, образы четвертого порядка - пространственно-подобные образования; образы пятого порядка - невербальные эталоны моральных, философских, математических обобщений. Согласно авторскому предположению, образы высших порядков - полимодальны, и включают в себя не только обобщенную образную, на и аудиальную информацию, иначе говоря, обладают своим звучанием; звучание может быть представлено бессвязными звуками, обобщенными частями слов, а также механически запечатленными словосочетаниями. Согласно классическим представлениям, понимание происходит, когда слово соединяется с образом, это положение в статье дополняется условием, что подлинное понимание происходит, если запечатленные первосигнальные звучания в составе образов высших порядков хотя бы частично совпадают со звучаниями слов, которыми данная категория определяется.
\end{abstract}

Ключевые слова: образы, психические образы, вторичные образы, слова, внутренняя речь, понимание, осознание, сознание, сновидения, осознанные сновидения.

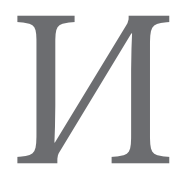

нформация об окружающем мире поступает в психику или в виде образов, или в виде слов. Но информации недостаточно поступить, ее надо понять, а чтобы понять, ее надо принять, встроив в систему уже имеющегося знания. О том, что понимание представляет собой связь слова и образа предполагал еще основатель эмпирического метода Т. Гоббс. В своей работе «Левиафан» он утверждал, что «понимание есть не что иное, как представления (имеются в виду образы представления - прим. мое Т.Б.), вызванное речью» ${ }^{2}$ В современной психологии это положение получило развитие как в эмпирических исследованиях, так и в теоретическом аспекте; согласно классическому определению понимание - это психический процесс включения каких-либо знаний в прежний опыт субъекта, в систему его ранее освоенных понятий и постижение на этой основе смысла и значения собы-

Гоббс Т. Левиафан, или Материя, форма и власть государства церковного и гражданского // Гоббс Т. Сочинения: в 2 т. Т. 2. М.: Мысль, 1991. тия или сути и содержания образа ${ }^{2}$. М.Е. Бершадский определяет понимание как два взаимосвязанных и взаимообусловленных процесса: ассимиляции информации с помощью наличных когнитивных схем и аккомодации познавательного опыта путём трансформации уже известных или формирования новых интеллектуальных действий и когнитивных схем ${ }^{3}$.

В своем исходном значении, в рамках герменевтической традиции понимание рассматривалось в основном как постижения смысла новой информации выраженной вербально, как понимание текстов или речей других людей. Поэтому основой понимания считалась интерпретация, которую личность дает понимаемому понятию ${ }^{4}$, иначе говоря, смысл одних слов понимался

\footnotetext{
2 Дьяченко М.И., Кандыбович Л.А. Психологический словарь-справочник. М.: Харвест, 2004. 266 с.

3 Бершадский М.Е. Понимание как педагогическая категория. (Мониторинг когнитивной сферы: понимает ли ученик то, что изучает?). М.: Центр «Педагогический поиск», 2004. 176 с.

4 Гадамер Х.-Г. Истина и метод. М.: Прогресс, 1988.
} 


\section{Философия и психология}

через выражение его другими словами, личностно близкими субъекту

Постижение сути информации, репрезентированной образно, - значительно более сложный процесс. Однако в современных теориях при формировании понимания подчеркивается необходимость учитывать не только вербальную, но и невербальную информацию. В.В. Знаков определяет понимание через опору на невербальное знание: «понимание некоторых событий и ситуаций происходит при опоре не на достоверное, допускающее эмпирическую проверку знание, а на личностное. Структура последнего в значительной степени основана на неосознаваемом невербализуемом знании, которое можно только постигать» ${ }^{6}$.

В физиологии высшей нервной деятельности понимание рассматривается, как возникновение ассоциативных связей между стимулами первой и второй сигнальной системы, то есть именно как связь между образом и словом.

Обычно такое определение относят к очень простым стимулам, последователи И.П. Павлова для иллюстрации понимания рассматривают примеры соединения конкретных образов с конкретными словами. Как пишут Н.Н. Данилова и А.Л. Крылова: «Слово начинает заменять обозначаемый им предмет. Эта способность появляется у ребенка к концу первого года жизни или началу второго. Однако слово сначала замещает лишь конкретный предмет, например данную куклу, а не куклу вообще, т.е. слово выступает на этом этапе развития как интегратор первого порядка.

Превращение слова в интегратор второго порядка или в «сигнал сигналов» происходит в конце второго года жизни. Для этого необходимо, чтобы на него было выработано не менее 15 различных условных связей (пучок связей). Ребенок должен научиться оперировать с различными предметами, обозначаемыми, одним словом. Если число выработанных условных связей меньше, то слово остается символом, который замещает лишь конкретный предмет. Между 3 и 4 годами жизни появляются слова - интеграторы третьего порядка. Ребенок начинает понимать такие слова, как «игрушка», «цветы», «животные». К пятому году жизни у ребенка возникают более сложные понятия. Так, слово «вещь» он относит и к игрушкам, и к посуде, и к мебели, и т.д.» ${ }^{7}$.

\footnotetext{
5 Виноград Т., Флорес Ф. О понимании компьютеров и познания // Язык и интеллект / под ред. В.В. Петрова. М.: Прогресс, 1996. С. 185-229.

6 Знаков В.В. Понимание, постижение и экзистенциальный опыт // Вопросы психологии. 2011. № 6. С. 20.

7 Данилова Н.Н., Крылова А.Л. Физиология высшей нервной деятельности. Ростов-н/Д: Феникс, 2005. С. 424-425.
}

Из этого отрывка видно, что авторы предполагают усложнение лишь системы слов, которые становятся интеграторами все большего порядка, образы же остаются неизменными; развитие же заключается в том, что слово соединяется со всем большим количеством конкретных образов. На наш взгляд, это не совсем так. Например, в концепции двойного кодирования А. Пайвио ${ }^{8}$ утверждается, что образная информация в долговременной памяти также обобщается, образуя все более сложные имагены (образы). Выделяется уровень конкретных имагенов (имагены «кошка» или «собака»), уровень обобщенных имагенов (имаген «животное»), уровень безымянных имагенов. На любом уровне имагены остаются обобщенными образованиями наглядной информации, связанной с системой слов, но независимой от нее.

По всей видимости, понимание здесь будет означать возникновение связи не только между конкретными образами и словами, но и между абстрактными понятиями и безымянными имагенами.

Ранее мы предположили существование модели образной системы, включающей в себя образы интеграторы различных порядков ${ }^{9}$. Порядки выделяются по аналогии с уровнями интеграции во второй сигнальной системе $^{10}$. Образы нулевого порядка - чувственные образы. Образы первого порядка - аналогичны образам эйдетической памяти, фотографичны. Образы второго порядка - классические вторичные образы, образы конкретных предметов, наглядны, обладают свойствами обобщенности, текучести и ряда других. Образы третьего порядка - представляются в виде контура, обобщающего форму многих предметов. Образы четвертого порядка - пространственные образования, образы высшего уровня обобщения предметов, не обладают свойством наглядности Образы пятого порядка невербальные эталоны моральных, философских, математических обобщений.

Особый вопрос о происхождении образов высшего порядка. Дискуссия о происхождении обобщенного знания ведется в психологии с глубокой древности. Еще в XVIII в. эмпиристы считали, что высшие знания происходят путем обобщения чувственного опыта (чувственных образов, иначе говоря), от простого к сложному. Рационалисты утверждали обратное,

8 Paivio A. (1978). The relationship between verbal and perceptual codes. In E.C. Carterette \& M.P. Friedman (Eds.), Handbook of Perception, V. 8 (pp. 375-397). London: Academic Press.

9 Березина Т.Н. Психические образы высших порядков в структуре образной формы // Психология и психотехника. 2012. № 1. C. 13-25.

10 Березина Т.Н. О психических образах высших порядков // NB: Психология и психотехника. 2012. № 2. С. 77-105. 


\section{Психология и психотехника 6(57) • 2013}

предполагая, что наиболее сложные знания априорно существуют в сознании, например, в виде врожденных идей (Р. Декарт), и постижение сущего осуществляется от сложного к простому. В начале XX в. дискуссию продолжили представители структурализма, с одной стороны, и гештальтпсихологии, с другой. Представители гештальтпсихологии полагали, что первичными данными психики являются целостные структуры (гештальты), в принципе не выводимые из образующих их компонентов. В настоящее время существуют теории, выходящие за пределы этой дихотомии. Например, в гипотезе об экстрасоматической природе памяти E.M. Иванов, что в памяти хранятся не образы или понятия, а наш мозг обладает способностью прямого доступа к прошлому, точнее к прошлым состояниям сознания, а ещё точнее к образам, которые воспринимались в тот момент. Таким образом, в нашей памяти хранятся только коды, направляющие нас в тот момент, когда информация воспринималась ${ }^{11}$, впрочем воспринималась она все равно в виде образа, а значит вопрос о его понимание остается.

Говоря о формировании образов высшего порядка, обычно мы опирались на модель «от простого к сложному». В частности, мы утверждали, что образы каждого последующего порядка возникают благодаря обобщению наглядной информации предшествующего. В качестве возможного механизма мы предположили существование нейрофизиологического аналога компьютерной операции прототипирования, позволяющий на основе нескольких различных фотографий объектов получить усредненный образ. С помощью компьютерных технологий созданы обобщенные портреты киногероев, типичного европейца или типичного азиата. При прототипировании изображения накладываются, общие элементы при этом усиливаются, а индивидуальные различия стираются. Мы предполагали, что аналогично формируются психические образы высших порядков. Однако, при зрелом размышлении, мы решили, что различия в возможных механизмах формирования образов высших порядков для нас не принципиальны, а имеет значение лишь сам факт существования таких образов. Возможно, что некоторое (или даже большая часть) образов высшего порядка являются врожденными структурами, как некие формы, лишенные собственного содержания, наподобие архетипов К. Юнга. Но в этом случае они и подавно не поддаются пониманию, без того, чтобы их форма ни заполнилась содержанием в виде более простых образов, то есть, все равно будет происходить накопление чувственных образов и их последу-

11 Иванов Е.М. Гипотеза об экстрасоматической природе памяти // NB: Философские исследования. 2013. № 8. С. 1-69. ющее обобщение. Наличие же врожденных гештальтов при этом будет лишь задавать направление обобщения. Кроме этого, мы можем предположить, что такие образы высших порядков являются многозначными (подобно двойным картинам, типа «жена-теща»), и в зависимости от заполняемого их конкретного содержания, может высветиться какое-то одно значение, а остальные останутся в тени. Поэтому обобщение в любом случае будет иметь место, а многие свойства самих образов высших порядков останутся неизменными.

Ранее мы также утверждали, что образы высших порядков - полимодальны, и что обобщению подвергается не только зрительная информация, но и информация, поступающая от других органов чувств, в частности, аудиальная. А поэтому, мы утверждали, что слово в нашей психике представлено двояко: как значение и как звучание ${ }^{12}$. Как значение оно представлено второй сигнальной системой И.П. Павлова, является компонентом сознания, изучается в психосемантическом направлении. Как звучание оно входит в состав чувственной ткани, становится составляющей психического образа, и обрабатывается наряду с другой наглядной информацией при формировании образов высших порядков. Наличие собственного аудиального компонента образов можно наблюдать в измененных состояниях сознания ${ }^{13}$. Связь образа со словом может рассматриваться в аспекте изучения внутреннего мира личности ${ }^{14}$.

\section{Аудиальный компонент психических образов}

Существование аудиального компонента образа показано для образов эйдетической памяти (образов первого порядка в нашей модели). Эйдетики, представляя образы каких-либо событий прошлого, наряду с элементами других модальностей включают в них и звуковой компонент. А.Р. Лурия приводит в качестве примера синестезий разговор с известным мнемонистом Ш.: «Нет, что вы, - ответил он, - разве можно забыть? Ведь вот этот забор - он такой соленый на вкус и такой шершавый, и у него такой острый и пронзительный звук...» ${ }^{15}$.

12 Березина Т.Н. Психические образы высших порядков: слово как звучание и как значение // Вестник МГГУ им. М.А. Шолохова. Серия «Педагогика и психология». 2012. № 4. С. 71-83.

13 Кучеренко В.В., Петренко В.Ф., Россохин А.В. Измененные состояния сознания: психологический анализ [Электронный ресурс] // http://www.e-puzzle.ru/page.php?id=3385.

14 Березина Т.Н. Исследование внутреннего мира человека методом анализа характеристик мысли и образа // Психологический журнал. 1999. Т. 20. № 5. С. 27.

15 Лурия А.Р. Маленькая книжка о большой памяти. М., 1968. C. 26. 


\section{Философия и психология}

Аудиальный компонент образа второго порядка складывается из собственных вокализаций объекта, звуков, которые звучали в момент восприятия, а также слов окружающих людей, называющий предмет. Существование такого аудиального компонента психических образов заметно у детей и проявляется в явлении автономной речи. Собственное звучание проявляется в том, что в определенном возрасте дети начинают давать собственные имена окружающим предметам. Автономная речь достаточно хорошо изучена. Считается, что она значительно отличается от взрослой речи и по звуковой форме (фонетическому строению), и по смыслу (семантической стороне). Детские слова по своему звучанию иногда напоминают «взрослые», иногда резко отличны от них. Встречаются слова, непохожие на соответствующие слова взрослых (например, «ика» - шкаф, «пшигилича» - карандаш), слова - обрывки слов взрослых («как» - каша, «па» - упала), слова - искажения слов взрослых, сохраняющие, тем не менее, их фонетический и ритмический рисунок («тити» — часы, «ниняня» — не надо), звукоподражательные слова («ав-ав» - собака, «му-му» - корова) ${ }^{16}$.

Надо сказать, что «собственное звучание образа» не есть явление постоянное, застывшее, оно меняется по мере того как ребенок впитывает новые звуки и новые звучания. И вполне естественно, что наиболее частым звуком, который войдет в состав образа конкретного предмета будет звучание его собственного названия, произносимого другими людьми. Поэтому в отношении конкретных предметов образы обычно соответствуют словам, а слова - образам. Иначе говоря, в образе кошки присутствует звучание «кошка», однако, наряду с адекватным звучанием, в образе присутствуют и другие звуки, сопровождавшие животное при его восприятии. Вероятно, в образе кошки есть ее собственная вокализации (мур, мяу), звуки, которыми ее наиболее часто подзывают (кис-кис). У взрослого человека автономная речь вытесняется, заменяясь нормальной взрослой речью, однако, ее элементы сохраняются где-то в глубинах подсознания. Отсюда и элементы «автономной» речи взрослых, выражающиеся в самоназваниях предметов, в частности, наименовании кошек - кисками или мурками, свиней - хрюшками, по всей видимости, потому что такое звучание существует у этих образов.

Мы полагаем, что аудиальная информация также сохраняется и обобщается при формировании образов третьего четвертого и пятого порядков.

Образы третьего и четвертого порядков, представляющие собой результат наложения изображений

16 Кураев Г.А., Пожарская Е.Н. Возрастная психология: Курс лекций. Ростов-на-Дону: УНИИ валеологии РГУ, 2002. животных (имаген «животное»), предметов домашнего обихода («мебель»), живых существ («живое существо»), включают в себя не только обобщенный зрительный конструкт, но и обобщенное звучание. Во-первых, в некоторых имагенах, например, в имагене «животное» в качестве звучания могут быть представлены вокализации самих животных. Во-вторых, в «немых» имагенах обобщенное звучание может складываться из наложения слов, которые произносили другие люди, называя предметы, образы которых оказались интегрированными. А.Р. Лурия описывал формирование некоторых обобщенных звучаний, утверждая, что в памяти будет храниться фонема «стл», как обобщение слов «стлать», «постилать», «настил», да и собственно стол ${ }^{17}$. В-третьих, поскольку образы третьего и четвертого порядка обобщают наглядную информацию, изначально представленную во вторичных образах, то каждый образ высшего порядка ассоциативно связан со звучаниями всех интегрированных в нем имагенов. Поэтому в образах третьего и четвертого порядка могут оказаться запечатленными целые фразы, предложения и словосочетания, которые звучали в момент восприятия его элементов и механически «записались» в память.

Сложнее всего формируются образы пятого порядка, представляющие собой невербальные эталоны обобщения философской, морально-нравственной, математической и т.п. информации. Образы пятого порядка весьма сложные образования, они - результат предельного обобщения наглядной информации, хотя сами наглядными не являются.

Для них мы предположили другой механизм формирования: образы пятого порядка возникают на базе обобщения информации, заложенной в образах предшествующих порядков, но это обобщение не столько структурное, сколько динамическое (если подбирать компьютерный аналог, то было бы накладывать нужно не фото, а видео), и не столько формальное, сколько содержательное. Если образы всех прочих порядков можно было получить наложением структур, то здесь накладываться должны отношения между структурами.

Говоря об аудиальном компоненте образов пятого порядка, необходимо иметь в виду, что они являются центром интеграции множества образов более низкого порядка, поэтому собственное звучание такого интегратора должно включать в себя звучания многих интегрированных элементов.

Ранее, мы предлагали гипотетическое формирование имагена «справедливость». «Ребенок видит картину того, как мальчик ударил кошку, а кошка

17 Лурия А.Р. Язык и сознание. М.: МГУ, 1979. 


\section{Психология и психотехника 6(57) • 2013}

его за это поцарапала, потом он смотрит, как воспитательница в детском саду распределяет игрушки, каждому по одной; далее им с мамой в метро какойто дядя уступает место, и т.п. Что общего в этих всех сюжетах? Это очень важный вопрос, потому что это общее, причем пространственно выделенное, и будет образом пятого порядка, тождественным понятию «справедливость»» ${ }^{18}$.

Общение наглядной информации, представленной во всех этих картинах и станет неким безымянным имагеном, ассоциативно связанным с конкретным образами, вошедшими в его состав (воспитательницей, кошкой и т.п.). Однако в нем будет не только обобщенная образная, но и обобщенная звуковая информация. Какая именно определяется индивидуально.

Более изученным является обратный процесс, представление элементов образной информации внутри вербальной. Согласно концепции сознания Ф.Е. Василюка, образы (чувственная ткань) являются сквозной характеристикой сознания, входящие во всех остальные компоненты. «Образ предстает перед нами не как внешняя по отношению ко всем этим мирам сущность, извне со стороны детерминируемая ими, а как часть каждого из них, как их интеграл, поле их интерференции, «голограмма», в которую вливаются волны и энергии всех этих миров, не сливаясь в аморфную массу, но и не оставаясь отдельными, а входя в такое единство, как отдельные голоса в многоголосье» ${ }^{19}$. В данной концепции утверждается, что образы входят в состав любых вербальных конструктов (слов, значений, знаков), мы согласны с этим утверждением, только хотели расширить понятие образа и включить в него, наряду со зрительным, еще и аудиальный компонент.

Частично это проявилось уже в некоторых эмпирических данных Ф.Е. Василюка. «Испытуемый М. на слово «справедливость» рисует человечка и рядом с ним вытянутую узкую полоску, так комментируя свою пиктограмму: «Человек показывает, что справа — длинная труба». Сознание испытуемого не идет от стимульного слова к тому или иному аспекту стоящего за словом содержания - к предмету ли, к понятию, к личным переживаниям, связанным со справедливостью, сознание задерживается на самом слове, на его «звуковой форме». Оно начинает играть со звуковой оболочкой слова, разбирая его на части и собирая из него новые слова, в

18 Березина Т.Н. Психические образы высших порядков в структуре образной формы // Психология и психотехника. 2012. № 1. C. 23.

19 Василюк Ф.Е. Структура образа (К 90-летию со дня рождения А.Н. Леонтьева) // Вопросы психологии. 1993. № 5. C. 13 . «сумме» созвучные первому, «справа-длинная»» ${ }^{20}$. Разумеется, одним таким простым звучанием аудиальный компонент образа «справедливость» не исчерпывается, но изучение полного его состава - это отдельная задача, выходящая за пределы данной статьи.

Образы пятого порядка, также как и четвертого, являются пространственно-подобным образованием, то есть переживаются как «место в пространстве», а не как изображение, однако, между ними есть одно важное различие. Поскольку в структурах пятого порядка интегрируется динамическая, а не статическая информация, то актуализации и, как правило, визуализацией прототипов: образов ситуаций, отношений, переживаний в динамике. Каждый из прототипов обладает своим звучанием.

\section{Соединение слова и образа}

В педагогике понимание начинается с объяснения. Объяснение - это второсигнальный процесс, при котором новая информация представляется вербально с опорой на логику и некоторые общие правила ее построения.

Автор, предлагающий новое знание, вводит новое слово - понятие, после чего дает его вербальное определение, в котором используются более простые понятия, определенные ранее. Определение новых понятий подчиняется законам формальной логики, в пределе определение новых понятий может быть иллюстрировано математическими законами: системой нескольких аксиом и последующим выводам из них с помощью формул все более и более сложных законов. Следует учесть, что в такой форме знания оказываются оторванными от наглядного содержания, то есть, могут быть оторванными, а могут и не быть оторванными, но в любом случае, вполне возможно, например, пользуясь формулами породить несуществующие в реальности комбинации. Как, например, в известной искусственной фразе, созданной на основе русского языка, в которой все корневые морфемы заменены на бессмысленные сочетания звуков: «Гло́кая ку́здра ште́ко будлану́ла бо́кра и курдя́чит бокрёнка». Разумеется, никто не ставит перед собой целью создавать искусственные фразы, и несуществующие определения, наоборот, цель любого исследователя сделать предлагаемое им новое знание максимально доступным для последователей, поэтому он тщательно подбирает слова, чтобы выразить суть нового понятия.

Однако понять что-то возможно только, если соответствующий этому образ высшего порядка в психике

\footnotetext{
20 Там же. С. 13.
} 


\section{Философия и психология}

реципиента уже сформирован, или находятся в процессе интеграции, и тогда объяснения могут помочь его формированию. Если же интегрального образа нет, человек не поймет, как бы красиво и правильно ему не объясняли. Наличие же у образов высшего порядка собственного звучания не усложняет, а лишь облегчает формирование устойчивого понимания.

В общем случае возможно два варианта взаимодействия слова и образа.

Первый вариант: собственное звучание образа частично или полностью совпадает с соответствующей вокализацией понятия. Звучащее слово в этом случае представляет собой условный стимул, а образ, связываемый с ним, оказывается чем-то вроде условной реакции. Однако актуализация образа пробуждает его собственное звучание, которое в этот момент является уже первосигнальным раздражителем, и которое может вызвать свою реакцию (на наш взгляд, безусловную) - эта реакция происходит уже внутри второй сигнальной системы - собственно это все то же звучание слова, но теперь оно является актуализированной частью значений языкового тезауруса. Иначе говоря, происходит переход аудиальной информации из первой во вторую сигнальную системы, это почти такой же процесс превращения звуков речи в систему слов - значений, только в данном случае звуки - внутренние. Поскольку актуализировавшиеся значения более или менее совпадают с первоначально прозвучавшими словами объяснения, в этом случае происходит завершение нейрофизиологического кольца, что и приводит к формированию устойчивого психологического гештальта. На уровне сознания это воспринимается как понимание.

Второй вариант: собственное звучание образа отлично от вокализации определяемого понятия. Словоопределение, как и в предыдущем варианте, выступает в роли условного стимула; образ, сочетаемый с ним становится условной реакцией. Аудиальный компонент вызванного образа оказывается в свою очередь новым стимулом, порождающим свою безусловную реакцию, эта реакция актуализации соответствующих звукам значений. Но это другие значения, нежели те, что прозвучали вначале. Кольцо не замывается, потенциалы возбуждения рассыпаются по нервной системе, пропадая втуне, гештальт не завершается. В простейшем случае это ощущается как когнитивный диссонанс, когда слово или определение представляются не соответствующими обозначаемому ими явлению. А чаще такое определение просто не запоминается.

Добавим, что идеи кольца как нейрофизиологической основы психических явлений предлагались многими исследователями ${ }^{21}$. Согласно Дж. Эдельману именно благодаря «повторному входу» (re-entering) возбуждения происходит интеграция отдельных признаков стимула в единый образ ${ }^{22}$. В теории функциональных систем П.К. Анохина, кольцо замыкается, когда образ полученного результата совпадает с акцептором результата действия, в концепции нервной модели стимула Е.Н. Соколова кольцо замыкается, когда происходит информация об объекте сравнивается с образом, хранящимся в памяти ${ }^{23}$, в концепции информационного синтеза А.М. Иваницкого именно движение возбуждения по кольцу обеспечивает восприятие объекта. «Возврат возбуждения и сравнение новой информации с памятью - фундаментальный принцип организации процессов мозга, лежащих в основе субъективного опыта. Его специфика определяется топографией центров» ${ }^{24}$.

Понимание образов второго порядка. Это база. Это основа формирования всех будущих интеграторов высших порядков. Это соединение конкретных слов с предметными образами, и, как правило, у взрослого человека они соединены адекватно: слово соответствует образу, и образ слову.

Основа такой адекватности закладывается в детстве, и тогда, когда связь слова и образа только формируется, возможно пронаблюдать и ситуацию понимания, и ситуацию диссонанса.

Наглядный пример этому - переход у ребенка от автономной к нормальной взрослой речи. Родитель показывает на предмет и сообщает его название. Если название предмета более или менее совпадает с собственным звучанием образа, то возникнет понимание. Это возможно в случае, когда собственное звучание, например, представляет собой искаженную речь взрослого. «Это часы» — говорит взрослый; «тити» — соглашается ребенок. Несовпадение аудиального выражения слова как понятия с собственными звуками образа ведет к диссонансу. Пример, такого диссонанса можно найти у Г. Линднера: перед ребенком, смотревшим на часы, несколько раз произносилось слово «тик-так»;

21 Назаров А.И. От рефлекторного кольца к многосвязной системе // Методология и история психологии. 2009. № 2. C. 32-44.

22 Edelman G.M., Tononi G. Consciousness: How matter becomes imagination. London: Pinguin Books, 2000. 274 p.

23 Соколов Е.Н. Очерки по психофизиологии сознания. М.: МГУ, 2010.

24 Иваницкий А.М. Проблема «сознание и мозг» и искусственный интеллект // Научная сессия МИФИ-2006. VIII всероссийская научно-техническая конференция «нейроинформатика-2006»: лекции по нейроинформатике. М.: МИФИ, 2006. C. $74-86$. 


\section{Психология и психотехника 6(57) • 2013}

когда затем то же слово повторялось, ребенок обращал взгляды на часы. По мнению автора, у ребенка создалась связь между звуком и некоторой ситуацией ${ }^{25}$. Однако когда такому ребенку другой взрослый, показывая на часы, скажет: «Это часы», - у него возникнет диссонанс, потому что внутри него этот образ звучит «тиктак». Этот диссонанс может проявляться в явлении пролонгирования автономной речи, когда ребенок отказывается называть «взрослое» слово, желая использовать сое собственное. К. Штумпф приводит в пример своего сына, который дал собственное название камню, утверждая, что камень выглядел именно так, как звучит это слово. Другой пример можно взять из нашей предыдущей работы. Девочка в детстве называла варежки - собственным словом «ля», став старше, она смогла выразить свое тогдашнее состояние: «Взрослые удивлялись: «Ну почему варежки ты называешь «ля»? И мне хотелось ответить, потому что они «ля», потому что они выглядят как «ля», потому что они ощущаются как «ля», потому что они «ля» и ничем другим быть не могут» ${ }^{26}$.

Впрочем, подобному диссонансу вряд ли суждено просуществовать долго, поскольку аудиальный компонент образа может меняться; и чем чаще взрослые произносят свое «взрослое» слово в присутствии предмета, тем скорее у образа появиться новое звучание, которое вытеснит детское звучание. И, в конце концов, возникнет понимание, слово будет выглядеть как предмет, а предмет будет звучать как слово.

В рассмотренных выше примерах, источником собственных звучаний образа выступали сцепленные с этим образом ранее слышанные слова или звуки. Другим источником собственного звучания образа является феномен синестезий. Его можно пронаблюдать даже у взрослых людей. А.Р. Лурия описывает человека феномена Ш., обладавшего именно такой памятью: «Переживания Ш. были совершенно другими. Он остро чувствовал, что есть слова, которые точно соответствуют своему содержанию, есть такие, которые нужно подправить, а есть такие, содержание которых явно несвойственно им, которые, безусловно, продукт недоразумения ${ }^{27}$. Например, слово «жар» соответствует самому себе. А слово «свинья» - не соответствует. «И еще «свинья»! Ну, разве это может быть? «Свинья» - это что-то тонкое, элегантное... Вот то ли дело «хавронья»

25 Цит по: Рубинштейн С.Л. Основы общей психологии. СПб: Питер, 2012. 713 с.

26 Обоняние, реальность и шизофрения [Электронный реcypc] // http://experiment4.narod.ru/shiz.htm.

27 Лурия А.Р. Маленькая книжка о большой памяти. М., 1968. С. 54. или «а хазер» (евр. «свинья»). Это, действительно, она «хх...»: жирная, с толстым брюхом, с жесткой шерстью, на ней засохшая грязь... - «а хазер» ${ }^{28}$.

Что же касается «немых» образов, ведь бывают же картины беззвучных явлений природы, восприятие которых не сопровождалось никакими звуками, вероятно, у таких образов аудиальный компонент будет практически отсутствовать (если не считать элементов синестезий). Понимание «немых» образов, на наш взгляд, будет происходить сложнее. Слово, произносимое взрослым в отношении предмета, образ которого не имеет собственного звучания, не вызовет ни резонанса, ни диссонанса. С одной стороны, его будет труднее запомнить, с другой стороны, не будет происходить отвержения. Мы полагаем, что в этом случае через несколько повторений, в процессе обучения в образе аудиальный компонент все равно сформируется, при этом он будет формироваться сразу же конгруэнтным своему значению.

Таким образом, оказывается, что у взрослого человека, говорящего на родном языке и живущего в окружении аутентичной культуры, конкретные слова как значения практически всегда соответствуют своему вторичному образу.

Понимание образов высших порядков. В общем и целом, понимание имагенов высших порядков происходит по той же самой схеме, как и обычных вторичных образов: путем замыкания в кольцо значений и звучаний.

Но тут есть несколько нюансов. Как правило, соответствующие понятия вводятся в том возрасте, когда образная сфера уже достаточно сформирована. Следует учесть, что формирование образов третьего, четвертого и пятого порядков - результат внутренней работы психики. Они подлинно внутренние образы. Таким образам невозможно найти иллюстрирующий их предмет во внешнем мире. Нет конкретного предмета «вещь» или объекта «животное», поэтому невозможно установить связь, просто указав на предмет и произнеся его название. Образы высших порядков являются интеграторами, поэтому они включают в себя соединения многих изображений с их собственными внутренними звучаниями. Соответственно сложным является и их определение. Например, исследователь вводит понятие «интеллект». Для этого он определяет данное понятие. Понятие определяется словами. Слова подбираются в соответствии с существующими научными теориями, авторскими предпочтениями и, самое главное, законами логики, законами языка, законами методологии данной науки и т.п.

\footnotetext{
28 Там же. С. 54.
} 


\section{Философия и психология}

Но в психике человека уже есть некие невербальные эталоны, которым можно поставить в соответствие понятие интеллект ${ }^{29}$. При этом, как нам кажется, такие эталоны несут огромный налет субъективизма, поскольку у разных людей может быть интегрирована в нем различная информация. У одного человека безымянный имаген на тему интеллекта обобщает образы учителя, парты, книги и т.п., а у другого образы Эйнштейна, Ньютона, Пифагора... Соответственно, такие образы будут обладать и разным звучанием. Впрочем, предположим, что у большинства людей жизненный путь похож (детсад, школа, ВУЗ), обобщается у них близкая информация, и собственное звучание образа будет схожим. Тем не менее, мы не знаем, что это за звучание. Мы знаем значение слова, его нам растолковали преподаватели, но собственное звучание наших глубинных образов нам неведомо, поскольку образ, еще несоединенный с системой языкового тезауруса бессознательный.

Каждое из слов определения вызывает свои образы, образы порождают свои звучания. Звучания порождают значения. Если большая часть актуализированных значений входят в авторское определение, то возникает понимание, только основой здесь будет не столько кольцо, сколько сеть из множественных соединений. Если же эти значения иные, чем слова, употреблявшиеся для определения понятия, возникает диссонанс и новое определение не включается в систему знаний субъекта. И исправить это сложнее, чем добиться конгруэнтного звучания у «немых» вторичных образов, поскольку собственное звучание образов будет сопротивляться попыткам механического запоминания не принятого психикой определения. В самом сложном случае слова из определения вообще не способны привести к завершению гештальта, поскольку их набор не соответствуют образам ни из одного подходящего невербального эталона.

В реальности же мы чаще всего сталкиваемся с частичным пониманием, когда какая-то часть слов, актуализируемых интегрируемыми вторичными образами, входит в определение сложного понятия, а другая — нет.

Подведем итог. Нами разработана модель психических образов высших порядков на основе предположения, что наглядная информация обобщается независимо от вербальной, формируя все более усложняющиеся образования. Согласно нашей модели, образы первого порядка - фотографические образы, второго порядка - классические вторичные образы; третьего порядка - обобщенные образы, образы четвертого порядка - пространственно-подобные образования; образы пятого порядка - невербальные эталоны моральных, философских, математических обобщений. Образы высших порядков являются полимодальными, и включают в себя не только обобщенную образную, на и аудиальную информацию, то есть, обладают своим звучанием: звуками, а также словами и предложениями, но в их первосигнальном виде.

Понимание наглядной информации, заключенной в образах высших порядков нами рассматривалось как взаимосвязь слова и образа. Мы утверждаем, что подлинное понимание происходит, если запечатленные первосигнальные звучания в составе образов высших порядков хотя бы частично совпадают со звучаниями слов, которыми данная категория определяется.

\section{Список титературь:}

1. Белова С.С. Субъективная оценка интеллекта другого человека: эффект вербализаций // Социальный интеллект. Теория, измерение, исследования. М.: ИПРАН, 2004. С. 39-62.

2. Березина Т.Н. Интроспективный эксперимент: новые возможности старого метода // Вестник Московского государственного гуманитарного университета им. М.А. Шолохова. Педагогика и психология. 2010. № 4. C. 21-26.

3. Березина Т.Н. Исследование внутреннего мира человека методом анализа характеристик мысли и образа // Психологический журнал. 1999. Т. 20. № 5. С. 27.

4. Березина Т.Н. О психических образах высших порядков // NB: Психология и психотехника. 2012. № 2. С. 77-105.

5. Березина Т.Н. Психические образы высших порядков в структуре образной формы // Психология и психотехника. 2012. № 1. С. 13-25.

6. Березина Т.Н. Психические образы высших порядков: слово как звучание и как значение // Вестник МГГУ им. М.А. Шолохова. Серия «Педагогика и психология». 2012. № 3. (в печати).

7. Березина Т.Н. Смыслы жизни, добро, духовное развитие, определение их значения // Мир психологии. 2008. № 2. C. 115 .

29 Белова С.С. Субъективная оценка интеллекта другого человека: эффект вербализаций // Социальный интеллект. Теория, измерение, исследования. М.: ИПРАН, 2004. С. 39-62. 


\section{Психология и психотехника 6(57) • 2013}

8. Бершадский М.Е. Понимание как педагогическая категория. (Мониторинг когнитивной сферы: понимает ли ученик то, что изучает?). М.: Центр «Педагогический поиск», 2004. 176 с.

9. Василюк Ф.Е. Структура образа (К 90-летию со дня рождения А.Н. Леонтьева) // Вопросы психологии. 1993. № 5. C. 5-19.

10. Виноград Т., Флорес Ф. О понимании компьютеров и познания // Язык и интеллект / под ред. В.В. Петрова. М.: Прогресс, 1996. С. 185-229.

11. Гадамер Х.-Г. Истина и метод. М.: Прогресс, 1988.

12. Гоббс Т. Левиафан, или Материя, форма и власть государства церковного и гражданского // Гоббс Т. Сочинения: В 2 т. Т. 2. М.: Мысль, 1991.

13. Данилова Н.Н., Крылова А.Л. Физиология высшей нервной деятельности. Ростов н/Д: Феникс, 2005. 478 с.

14. Дьяченко М.И., Кандыбович Л.А. Психологический словарь-справочник. М.: Харвест, 2004. 266 с.

15. Знаков В.В. Понимание, постижение и экзистенциальный опыт // Вопросы психологии. 2011. № 6. С. 15-24.

16. Иваницкий А.М. Проблема «сознание и мозг» и искусственный интеллект // Научная сессия МИФИ-2006. VIII всероссийская научно-техническая конференция «нейроинформатика-2006»: лекции по нейроинформатике. М.: МИФИ, 2006. С. 74-86.

17. Иванов Е.М. Гипотеза об экстрасоматической природе памяти // NB: Философские исследования. 2013. № 8. С. 1-69.

18. Кураев Г.А., Пожарская Е.Н. Возрастная психология: Курс лекций. Ростов-н/Д: УНИИ валеологии РГУ, 2002.

19. Кучеренко В.В., Петренко В.Ф., Россохин А.В. Измененные состояния сознания: психологический анализ [электронный ресурс] // http://www.e-puzzle.ru/page.php?id=3385.

20. Лурия А.Р. Маленькая книжка о большой памяти. М., 1968.

21. Лурия А.Р. Язык и сознание. М.: МГУ, 1979.

22. Надыкто Е.А. Понимание как психологический аспект преемственной связи // Психология и психотехника. 2013. № 2. С. 162-171.

23. Назаров А.И. От рефлекторного кольца к многосвязной системе // Методология и история психологии. 2009. № 2. С. 32-44.

24. Петренко В.Ф. Вернем психологии сознание // Вестник МГУ. Серия «Психология». 2010. № 3. С. 121-141.

25. Петров В.О. Вокальная симфония: к вопросу о синтезе музыки и слова // Культура и искусство. 2013. № 1. C. 104-114.

26. Розенова М.И. Опыт психологического исследования представлений о любви на уровне обыденного сознания людей // Мир психологии. 2006. № 1. С. 241-254.

27. Рубинштейн С.Л. Основы общей психологии. СПб: Питер, 2012, 713 с.

28. Соколов Е.Н. Очерки по психофизиологии сознания. М.: МГУ, 2010.

29. Edelman G.M., Tononi G. Consciousness: How matter becomes imagination. London: Pinguin Books, 2000. 274 p.

30. Paivio A. (1978). The relationship between verbal and perceptual codes. In E.C. Carterette \& M.P. Friedman (Eds.), Handbook of Perception, V. 8 (pp 375-397). London: Academic Press.

\section{References (transliteration):}

1. Belova S.S. Subektivnaya ocenka intellekta drugogo cheloveka: effekt verbalizaciy // Social'nyy intellekt. Teoriya, izmerenie, issledovaniya. M.: IPRAN, 2004. S. 39-62.

2. Berezina T.N. Introspektivnyy eksperiment: novye vozmozhnosti starogo metoda // Vestnik Moskovskogo gosudarstvennogo gumanitarnogo universiteta im. M.A. Sholohova. Pedagogika i psihologiya. 2010. № 4. S. 21-26.

3. Berezina T.N. Issledovanie vnutrennego mira cheloveka metodom analiza harakteristik mysli i obraza // Psihologicheskiy zhurnal. 1999. T. 20. № 5. S. 27.

4. Berezina T.N. O psihicheskih obrazah vysshih poryadkov // NB: Psihologiya i psihotehnika. 2012. № 2. S. 77-105.

5. Berezina T.N. Psihicheskie obrazy vysshih poryadkov v strukture obraznoy formy // Psihologiya i psihotehnika. 2012. № 1. S. 13-25.

6. Berezina T.N. Psihicheskie obrazy vysshih poryadkov: slovo kak zvuchanie i kak znachenie // Vestnik MGGU im. M.A. Sholohova. Seriya «Pedagogika i psihologiya». 2012. № 3. (v pechati).

7. Berezina T.N. Smysly zhizni, dobro, duhovnoe razvitie, opredelenie ih znacheniya // Mir psihologii. 2008. № 2. S. 115.

8. Bershadskiy M.E. Ponimanie kak pedagogicheskaya kategoriya. (Monitoring kognitivnoy sfery: ponimaet li uchenik to, chto izuchaet?). M.: Centr "Pedagogicheskiy poisk", 2004. $176 \mathrm{s.}$ 


\section{Философия и психология}

9. Vasilyuk F.E. Struktura obraza (K 90-letiyu so dnya rozhdeniya A.N. Leonteva) // Voprosy psihologii. 1993. № 5. S. 5-19.

10. Vinograd T., Flores F. O ponimanii komp’yuterov i poznaniya // Yazyk i intellekt / Pod red. V.V. Petrova. M.: Progress, 1996. S. $185-229$.

11. Gadamer H.-G. Istina i metod. M.: Progress, 1988.

12. Gobbs T. Leviafan, ili Materiya, forma i vlast' gosudarstva cerkovnogo i grazhdanskogo // Gobbs T. Sochineniya: V $2 \mathrm{t}$. T. 2. M.: Mysl', 1991.

13. Danilova N.N., Krylova A.L. Fiziologiya vysshey nervnoy deyatel'nosti. Rostov n/D: Feniks, 2005. 478 s.

14. D'yachenko M.I., Kandybovich L.A. Psihologicheskiy slovar'-spravochnik. M.: Harvest, 2004. 266 s.

15. Znakov V.V. Ponimanie, postizhenie i ekzistencial'nyy opyt // Voprosy psihologii. 2011. № 6. S. 15-24.

16. Ivanickiy A.M. Problema «soznanie i mozg» i iskusstvennyy intellect // Nauchnaya sessiya MIFI-2006. VIII vserossiyskaya nauchno-tehnicheskaya konferenciya «neyroinformatika-2006»: lekcii po neyroinformatike. M.: MIFI, 2006. S. 74-86.

17. Ivanov E.M. Gipoteza ob ekstrasomaticheskoy prirode pamyati // NB: Filosofskie issledovaniya. 2013. № 8. S. 1-69.

18. Kuraev G.A., Pozharskaya E.N. Vozrastnaya psihologiya: Kurs lekciy. Rostov-na-Donu: UNII valeologii RGU, 2002.

19. Kucherenko V.V., Petrenko V.F., Rossohin A.V. Izmenennye sostoyaniya soznaniya: psihologicheskiy analiz [elektronnyy resurs] // http://www.e-puzzle.ru/page.php?id=3385.

20. Luriya A.R. Malen'kaya knizhka o bol'shoy pamyati. M., 1968.

21. Luriya A.R. Yazyk i soznanie. M.: MGU, 1979.

22. Nadykto E.A. Ponimanie kak psihologicheskiy aspekt preemstvennoy svyazi // Psihologiya i psihotehnika. 2013. № 2. S. 162-171.

23. Nazarov A.I. Ot reflektornogo kol'ca k mnogosvyaznoy sisteme // Metodologiya i istoriya psihologii. 2009. № 2. C. 32-44.

24. Petrenko V.F. Vernem psihologii soznanie // Vestnik MGU. Seriya «Psihologiya». 2010. № 3. S. 121-141.

25. Petrov V.O. Vokal'naya simfoniya: k voprosu o sinteze muzyki i slova // Kul'tura i iskusstvo. 2013. № 1. S. 104-114.

26. Rozenova M.I. Opyt psihologicheskogo issledovaniya predstavleniy o lyubvi na urovne obydennogo soznaniya lyudey // Mir psihologii. 2006. № 1. S. 241-254.

27. Rubinshteyn S.L. Osnovy obschey psihologii. SPb: Piter, 2012. 713 s.

28. Sokolov E.N. Ocherki po psihofiziologii soznaniya. M.: MGU, 2010.

29. Edelman G.M., Tononi G. Consciousness: How matter becomes imagination. London: Pinguin Books, 2000. 274 p.

30. Paivio A. (1978). The relationship between verbal and perceptual codes. In E.C. Carterette \& M.P. Friedman (Eds.), Handbook of Perception, V. 8 (pp. 375-397). London: Academic Press. 